\title{
The Experience of Islamic Art on the Margins of Islam
}

Irene A. Bierman, ed.

Reading, UK: Ithaca Press in association with the Gustav E. von Grunebaum Center for Near Eastern Studies, 2005. 172 pages.

This volume is the fifteenth publication in the Giorgio Levi Della Vida Conference Papers series, each of which contains the lecture presented by the recipient of the Giorgio Levi Della Vida Award for excellence in Islamic studies along with contributions by other scholars dedicated to a special topic. For the first time ever, in 1996 the award was presented to an art historian, Oleg Grabar, who chose "The Experience of Islamic Art on the Margins of Islam" as the theme of the fifteenth conference. 
The crossing of boundaries by artifacts, decorative elements, or figural subjects from one cultural hemisphere into another, as well as the perception of the "inherited" monuments of other cultures, is a broad and still largely unexplored field. While studies following the wandering of motifs are quite numerous, the reasons for their selection and tacit integration into new contexts, along with their reshaping and revaluation, are not dealt with very often. Each of the five articles directs our attention to a particular border area of Islamic culture during a particular period, ranging from the Middle Ages to the present. Each contribution also approaches the question of how (regardless of the way) acquired Islamic objects and monuments were dealt with from a specific angle. The result is a small and very diverse collection of experiences that surely does not offer an overview of all responses to Islamic art. However, it convincingly demonstrates how revealing research on the cultural margins can be.

In his three-part lecture entitled "The Experience of Islamic Art," Grabar first reviews his way into the field along different "Modes of Experience," assessing what each of them contributed to his approach and understanding of the Islamic world and its art and architecture. His other two essays, "The So-called Mantle of Roger II" and "The Ceiling of the Cappella Palatina," are dedicated to famous art works of Norman Sicily. Placing the mantle's origin in the private atmosphere of the women's quarters of Roger II's palace, he prefers an astrological interpretation of the representation on the mantle's outside over its reading as a mere symbol of power. Latest research (Nobiles Officinae, exh. cat. Vienna 2004) does not contradict this interpretation. Concerning the perception of Islamic elements along with Byzantine and Latin ones, Grabar argues for a more integrative view of Norman art. For its part, the smooth incorporation of Islamic art's motifs and objects was encouraged by their decorative value, which could be perceived as a purely formal quality when split apart from any possible messages. Moreover, if deemed fitting they could always be charged with new content.

This way of using the aesthetic qualities of Islamic art objects outside their realm generally worked, but sometimes unsettled its users when they suddenly realized an unwelcome substance connected to the admired form, as we learn in Robert S. Nelson's "Letters and Language/Ornament and Identity in Byzantium and Islam.” As a highly valued work of art, a Mamluk tray was used in an important church ceremony only as long as the clergy did not know that its epigraphic decoration contained the name "Muhammad.” Obviously, apart from a common visual language of power and splen- 
dor, accepting luxury items from the Islamic world was sometimes helped by a lack of understanding. The decisive role in these persuasion processes, however, was played by the magic of ornament, including the ornamental effect of color. Nelson also points to one of the rare post-Umayyad examples, the dying of the parchment in a high-status manuscript, the famous Fatimid Blue Qur'an, where aesthetic persuasion worked the other way round in relationship with the Christian world.

Zeynep Çelik, in her "Islamic Art and Architecture in French Colonial Discourse: Algeria, 1930," reminds us that appreciating Islamic art for its decorative values always had a disparaging aspect: it excluded Islamic art from "high art," which was not only restricted to painting and sculpture, but exclusively reserved for western painting and sculpture. Respectively, this approach extended into the field of architecture, although tendencies to discourage research on important monuments because of their "structural flaws" succeeded only partially. Çelik's main focus, however, is upon integrating art production and specific architectural features encountered in Algeria into the French colonial empire's perception, particularly upon the colonial administration's ideological and practical interest in the ethnographic exploration of domestic space.

The remaining two articles take us to one of the Islamic world's eastern frontiers: India. "The Articulation of Islamic Space in the Medieval Deccan,” by Richard M. Eaton, exposes the "Deccan's historiographical 'Maginot line"” of the fourteenth through the seventeenth centuries between the Muslim kingdoms to the north and the Vijayanagara kingdom to the south of the Krishna River as a primarily modern political construction enforced by academic conventions. Delimitation was already propagated by the ruling elites on both sides, for they were taking part in a common Islamicate culture. The article's second part is devoted to important differences in the definition of sacred space. Whereas the Vijayanagara rulers patronized traditional holy places and developed them into their legitimating spiritual centers, the Deccan's Muslim rulers turned to Sufi shaykhs, particularly of the Chishti order, as the most influential spiritual authority. "Those portable vessels of spiritual sovereignty" created new spiritual centers that simultaneously legitimized change and the extension of power.

While Eaton's contribution is more about crucial elements of Islamicate culture on a margin, the article by Richard H. Davis leads us back to architecture. His "Memories of Broken Idols" is the sad story of how perceiving a monument was deliberately reduced to just one aspect of its creation: its function as the symbol of a power that had faded away long ago. The Babri 
Masjid's destruction was prepared by the Hindu nationalists' interpretation of all mosques on Indian territory as reminders of destroyed Hindu temples. Looking back at the Islamic conquests and the symbolic acts, as well as the purposeful narratives connected to establishing a new power, the reader cannot but wonder about the recurrence in our time of ostentatious appropriation using the methods of the Middle Ages.

Summing up, the articles offer intriguing insights into perceptions of Islamic art and culture on the margins of Islam, both past and present. As an art historian always most attracted by research on the cultural, spiritual, political, and economic background of art objects, I wish, nevertheless, that objects and buildings, as works of art, had been given more space, including the number and quality of illustrations. The publication reflects, probably adequately, the place accorded by Islamic studies, up to now, to art as part of Islamic culture. If so, this is not Grabar's fault, whose inspiring work has contributed so much to gaining for Islamic art the place it deserves not only in our perception of Islamic culture, but also in the sphere of world art.

Karin Rührdanz

Curator of Islamic Art, Royal Ontario Museum

Toronto, Canada 